\title{
High and Low Leverage Choices: Some Evidence from Private Firms
}

\author{
Pietro Gottardo, Anna Maria Moisello \\ Department of Economics and Management, University of Pavia, Pavia, Italy \\ Email: pgottardo@eco.unipv.it
}

Received 10 February 2016; accepted 20 March 2016; published 23 March 2016

Copyright (C) 2016 by authors and Scientific Research Publishing Inc.

This work is licensed under the Creative Commons Attribution International License (CC BY).

http://creativecommons.org/licenses/by/4.0/

\section{(c) (i) Open Access}

\begin{abstract}
This paper studies the determinants of low and high leveraged financial structures analyzing a sample of 831 medium-large private firms, in the first and last quartile of the leverage distribution, using panel data and simultaneous equations procedures in the period 2001-2010. The empirical findings show that group membership and management factors influence financing decisions, and that internal capital markets, net working capital choices and product market position influence private firms' capital structure choices, consistently with a pecking order perspective. This study provides evidence on medium large private firms, which are quite unexplored compared to small businesses and to the public counterpart, relying on the theoretical framework of the Pecking Order Theory integrated by product market competition and internal capital market theories.
\end{abstract}

\section{Keywords}

Capital Structure, Low Leverage, Internal Capital Markets, Market Share, Liquidity

\section{Introduction}

One of the most fundamental questions in finance, which is the determinants of capital structure choices, still puzzles financial economists. The literature identified a number of factors that seem relevant in explaining some of the variation in corporate capital structure. Taxation and financial distress costs play a pivotal role in tradeoff theory. Asymmetric information is the key in pecking order theory supporting a financing hierarchy of internal funds, debt and equity.

A large body of evidence is based on listed firms, as data on private firm are limited, and few studies analyze the persistence of capital structure choices (e.g. Lemmon, Roberts and Zender [1]; Strebulaev and Yang [2]) focalizing on accounting variables without taking into account ownership and management characteristics and other relevant firm related variables, such as market power, group membership and internal capital markets. Moreover, we don't know if the determinants that model the dynamics of debt and equity at the level of the firm 
are the same in explaining the differences between firms. Last but not least, most of the variation in leverage is unaccounted for using previously identified determinants, as the adjusted R-squares of the usual model specifications range from $0 \%$ to $30 \%$.

The aim of the paper is to verify if low and high leveraged financial structures are contingent or they tend to be persistent over time, so we focus on firms in the first and last quartile of the leverage distribution as of 2010 . We find that private firms show differences in capital structures analogous to those found in previous studies for listed firms. Further, it does not seem that the Italian institutional and legal environments play a significant role in determining this evidence as large differences in leverage for privately held firms are also documented by Lemmon, Roberts and Zender [1] in UK. The persistence in leverage ratios shown in previous studies is not peculiar to listed firms as we find that private firms exhibit a similar pattern, regardless of whether they are low or high levered. A distinguishing feature between low and high-leverage firms is that, both in absolute or relative terms, the first resorts much more extensively to internal capital markets. This suggests that this kind of firm prefers to finance its needs primarily through internally generated funds and then borrow from parent or other firms of the same business group, a result highly consistent with some sort of pecking order.

We then analyze what lies behind the persistence and the capital structure choices, introducing two new sets of factors, three main empirical findings emerge.

The first is that there is strong evidence that ownership, group membership, and management factors affect capital structure choices beyond the indirect effects on profitability, tangibility or size. Panel results imply that foreign ownership, the position within a group or a standalone condition, the existence of a single shareholder and management age affect the leverage choices of private firms.

Second, the most important factors in explaining the persistence and the cross-sectional variability in leverage are liquidity, inventory and the commercial trade components of net working capital. Third, the evidence suggests that a firm's product market position and capital structure choices are closely connected: a firm with a high product market-share is likely to have lower leverage ratios. Thus, our main conclusion is that internal capital markets, net working capital choices, and product market position influence private firms' capital structure decisions. The results are, by and large, consistent with a pecking order perspective.

We contribute to the literature providing evidence on medium large private firms which are quite unexplored compared to small businesses, linking the capital structure, product market competition and internal capital market theories.

The remainder of the paper is organized as follows: Section 2 reviews the literature and formulates the related testable hypotheses; Section 3 describes the sample data; Section 4 discusses the descriptive statistics and the question of persistence in leverage; Section 5 examines the determinants of permanent leverage ratios; Section 6 discusses the results, limitations and provides suggestions for further research; Section 7 concludes.

\section{Hypotheses Development}

Capital structure is influenced by a complex interplay of variables and choices connecting the power to generate internal resources and how they are employed, the availability of intra-group coordination in the allocation of resources, the competitive strategies of the firm and the characteristics of its output market. Some of these variables are scrutinized in distinct streams of studies but we still lack a thorough understanding of how they interconnect.

Keynes [3] argues that a major advantage of a liquid balance sheet is that it allows firms to undertake valuable projects when they arise. But what exactly does a "liquid balance sheet" mean? A firm with high cash holdings could probably be referred to as "liquid" but the same is true for a firm with high net working capital or a firm that generates large cash-flows. Thus, the concept of a liquid balance sheet can be interpreted multi-dimensionally.

In their normal, everyday life firms must deal with complex and closely intertwined investment, financing, and risk-management decisions. In the limited case of financially-constrained firms investment depends on the ratio of marginal $q$ to the marginal value of liquidity, optimal external financing and payout are characterized by an endogenous double-barrier policy for the firm's cash inventory, and liquidity management and derivatives hedging are complementary risk-management tools (Bolton, Chen and Wang [4]). Moreover external capital markets are imperfect and if internal capital markets allocate capital within firms, an external shock that leads to a large decrease in cash-flow and collateral value can reduce investments (Lamont [5]). 
Centralization presents benefits and costs: headquarters can use excess liquidity from high cash-flow projects to buy continuation rights for low cash-flow projects, but they can also pool cash-flows from several projects and self-finance follow-up investments without having to return to the capital market (Inderst and Müller [6]), re-proposing the agency problem of free cash-flows (Jensen [7]). Firms with stronger growth opportunities, riskier cash-flows, and more limited access to external capital markets hold higher cash balances (Opler, Pinkowitz, Stulz and Williamson [8]). Financial flexibility and financial slack matter for investment but they also have far-reaching implications for the value of a firm (e.g. Gamba and Triantis [9]), competition (e.g. Chevalier [10]) and the probability of survival in tight market conditions and downturns. Hoarding cash has its pros and cons: managers may be tempted to misallocate excess liquidity for their own interest, destroying rather than creating value, but there are several rationales for holding cash in excess. These include impacting the competitive position of the firm so that it can quickly make investments in fixed and intangible assets, launching an advertising campaign or financing any other move necessary to indicate the firm's strength to existing or prospective competitors. However, cash stockpiling is just one of several competitive strategy weapons available: a profitable firm can rely on a strong balance sheet to curb a rival's moves, to improve its position through aggressive pricing or simply by granting more favorable credit terms to clients. POT (Myers and Majluf [11]) claims that firms follow a hierarchy of retained earnings, short-term borrowing, long-term borrowing and the latest equity issues in meeting capital needs and that they do not pursue any target leverage ratio. Firms would tend to maintain a stable financial structure to the extent that the capacity to generate internal resources is stable.

H1: Firms financial structure tends to be stable.

H1a: The shifting from high to low leverage is preceded by a stable increase in profitability and liquidity.

$\mathrm{H} 1 \mathrm{~b}$ : The shifting from low to high leverage is preceded by a stable reduction in profitability and liquidity.

\subsection{Management Ownership, Business Groups and Internal Capital Markets}

The crucial question is whether management ownership influences capital structure choices. While there is a relatively large body of literature, particularly related to widely held firms, on the effects of ownership on firm performance and value, (e.g. Franks and Mayer [12]), the relationship between ownership structure and capital structure remains largely unexplored. The evidence on the relationship between management ownership and leverage is also mixed; this could be the result of a non-linear relation. From anecdotal evidence we know that Italian businesses have, historically, adopted a high-debt policy as a source of financing, The Economist (2 March 2000) writes that: "Typically, Italian entrepreneurs have been loath to surrender even a small part of their equity capital to stock market investors. Instead, financing came from cash flow or bank loans".

Organizational forms may affect financing as business relations between member firms, cross-ownership stakes, the limited liability of firms within the group, incorporation into different jurisdictions, and other factors, can differentiate groups from standalone firms. In value-maximizing business groups, resources may be channeled to either more or less profitable subsidiaries. In other words, cases of both winner picking and cross-subsidization may occur (Cestone and Fumagalli [13]). The idea is that business groups may somehow behave differently in product markets and in the financing of their needs. Meyer and Kuh [14] were the first to note the relationship between investment and internal cash-flows and the use of internal capital markets in relation to the differences between the internal and external cost of funds. A firm's decision to operate an internal capital market affects the fundraising behavior of its competitors (Mathews and Robinson [15]). The headquarters of diversified firms themselves introduce another layer of agency problems, enabling managers to gain preferential investments for their divisions and providing evidence consistent with inefficient cross-subsidization (Scharfstein and Stein [16]). On the other hand, internal capital markets are efficient if corporate headquarters possess informational advantages relative to external investors and exploit all sources of value by allocating resources to their best use (Stein [17]).

Holdings would raise more debt than subsidiaries to reduce the cost of funds and take advantage of economies of scale (Piga [18]; Bianco and Nicodano [19]); moreover, lenders tend to grant more funds to parent companies at more favorable terms.

H2: Holdings are more levered than subsidiaries.

The affiliates of multinational firms are financed with less external debt in countries with underdeveloped capital markets and weak creditor rights (Desai, Foley and Hines [20]). This implies opportunistic behavior that impacts the capital structure and the competitive position of affiliates over local firms.

H2a: Control by a foreign company reduces leverage. 


\subsection{Firm and Industry Characteristics}

We believe that an efficient functioning of the internal market may also be found among local competitors or even purely local firms. It could be due to the imitative behavior between competitors, or to the perceived advantages in financing costs, resource allocation optimization and improved competition in the output market. This implies a strong link between resource generation, usage of the internal capital market and some measure of performance in the output market.

It is widely acknowledged that industry factors are important in the financial structure of firms although empirical evidence shows that there is wide variation in financial structure even after controlling for industry. This empirical regularity has been modeled as the outcome of several product market competition models. Efficient firms are more likely to survive and firm leverage reduces the probability of survival as competition increases (Zingales [21]), financial structure, technology and risk are jointly determined within industries (MacKay and Phillips [22]). The empirical evidence of Campello [23] suggests that moderate firm debt is associated with future market-share gains obtained at the expenses of industry rivals, while excessive leverage leads to product market underperformance.

H3: A strong position in the product market maintains the capacity to generate internal resources affecting leverage choices.

\section{Data and Variables Definition}

Our analysis is based on a unique dataset covering the whole population of non-financial Italian firms that comply with the following rules: they are incorporated as an SpA (Società per Azioni) or Srl (Società a Responsabilità Limitata), have revenues of over $€ 70$ million as of 2010 and are positioned in the first or the last quartile of total book leverage, with a minimum of three years' data, as identified from public sources such as AIDA (Italian Digital Database of Companies). AIDA is the Italian provider of Bureau van Dijk European Databases and represents the most reliable and comprehensive source of financial information for Italian private companies. The AIDA database covers 1 million companies in Italy providing accounts (following the scheme of the 4th EEC directive), indicators, trade description, ownership and management information. We disregard the financial companies because both their business and specific regulation strongly influence their capital structure. The threshold on a firm's revenues, which corresponds to a typical large or medium-sized Italian firm, ensures that most basic data items are available. We complement financial data from AIDA with hand-collected data on ownership and governance characteristics from official public filings, obtained from the Italian Chamber of Commerce (Company Register). Such filings represent the most reliable source of information for private companies in Italy and include all the changes in ownership and governance structure. The database covers ten years of data between 2001 and 2010. None of the firms in the dataset has consolidated accounts in the covered period, but, thanks to this, we are able to highlight the impact of intra-group operations on capital structure.

We use two basic definitions of leverage throughout this study. The first is total book leverage, defined as the ratio of total financial debt (both short term and long term) to capital (defined as total financial debt plus equity). The second is external book leverage, defined as total financial debt obtained from extra-group/shareholder sources to capital. Various firm characteristics have been found to influence capital structure choice (e.g., Barclay and Smith [24], Harris and Raviv [25], Rajan and Zingales [26]). The set of determinants used in many capital structure studies comprises in particular asset tangibility, firm size, and profitability. We measure asset tangibility with the ratio of net property, plant and equipment to total assets, and we use also the ratio of intangible assets to total assets. Firm size is measured as the logarithm of sales, and in the descriptive statistics we also report total assets. Firms' profitability is the ratio of operating income before depreciation to total assets. To these ratios we add two other sets of determinants. The first set consists of variables related to the management and ownership structure such as management ownership, family ownership, board of director size, the number of non-executive members on the board, and management age. Management ownership is the sum of direct and indirect voting rights as a percentage owned by all top executives. This is preferable to solely CEO ownership because, in Italian firms, all top executives (president, vice-president, and CEO) have comparable executive power and there is no clear ranking in authority between them. We measure family ownership by summing up the voting rights of all the members of a family with an interest in a given firm. Board size and non-executive members are the total number and the weight of non-executives members of the board, respectively, while management age is the age in years of the top executive. With the second set we incorporate into our analysis other firm cha- 
racteristics related to their balance sheet structure and output market structure. Specifically, these are depreciation, inventory, liquidity, treasury stock, commercial trade debt and credit, asset turnover, and the firm's market-share. Depreciation is measured as the ratio of depreciation of physical and intangible assets over total assets; inventory is the ratio of inventory to total assets and treasury stock the fraction of stock bought back by the firm. We define liquidity as the ratio of total cash and equivalents to total assets. To disentangle the impact of intra-group and extra-group operations we define Trade Debt $\mathrm{EXT}_{\mathrm{ET}}$ (Trade Debt $\mathrm{I}_{\mathrm{INT}}$ ) as the ratio of extra-group (intra-group) account payables to total assets, and Trade Credit $\mathrm{EXT}_{\mathrm{ET}}$ (Trade Credit $\mathrm{INT}_{\mathrm{NT}}$ ) as the ratio of extra-group (intra-group) account receivables to total assets. The asset turnover ratio is defined as the ratio of sales to total assets; it measures the efficiency of a firm's use of its assets. We compute market-shares using firms' revenues.

\section{Descriptive Statistics and Persistence}

Table 1(a) presents summary statistics for all of our firms as well as the two subsamples of firms referred to as "Low-leverage" and "High-leverage" while Table 1(b) presents the industrial breakdown of our sample showing the number of firms and the mean total leverage in each case. The "Low-leverage" is the subsample of firms in the first quartile of the distribution of total book leverage while the "High-leverage" is the subsample of firms in the last quartile of the same distribution. For High-leverage firms the mean total leverage is $73.01 \%$, with almost $99 \%$ originating from external creditors, while Low-leverage firms have a scant $6.36 \%$ mean total leverage and more than $54 \%$ originating from internal creditors such as shareholders, holdings or other related parties. These figures highlight a substantial difference between Low and High-leverage firms with respect to their financing choices. The leverage choice is permanent, or time-invariant, and it has, on average, a very long decaying period that can last for several decades. The persistence parameter in the table shows for how long during its life each firm maintains its leverage position. We see that Low-leverage firms stay low for, on average, 95.31\% of their life, or 9.5 out of 10 years of life; similar results are also obtained for High-leverage firms. Leverage positioning is, after all, a highly persistent phenomenon. Clear differences emerge in the balance sheet composition and other characteristics of Low and High-leverage subsamples. A quick comparison reveals that Low-leverage firms are larger than High-leverage ones, are much more profitable, have more tangible and intangible assets, hold substantially less inventory but similar levels of gross working capital while their amount of liquidity is more than double. Other striking differences emerge in the net working capital positions. Clearly these are partially the result of the differences in inventory and liquidity but they are also determined by trade credit and debt positions. The overall picture is that Low-leverage firms are, on average, net creditors with respect to extra-group trade operations and net debtors in their intra-group operations; on the other hand High-leverage firms have a stronger extra-group creditor position while they are net debtors in their intra-group operations. This evidence provides support for the view that internal capital markets are efficient and that corporate headquarters exploit all sources of value by allocating resources to their best use. Management owns, on average, $32.7 \%$ of the voting rights but its weight is lower in Low-leverage and significantly higher in High-leverage firms. This result mirrors that relative to family ownership; unsurprisingly top executives frequently belong to the controlling shareholder's family. It is unlikely that High-leverage firms suffer significant agency problems with management or minority shareholders given the level of control held by the family shareholders; however, it is likely that the potential conflict of interest between family members, and between controlling shareholders and creditors, is of more relevance. On the other hand, Low-leverage firms will see minimal levels of conflict with creditors and, potentially, the magnification of agency problems with minority shareholders. The asset turnover ratio reveals another difference between High and Low-leverage firms, with the latter having a lower turnover. The final striking difference between Low and High-leverage firms in Table 1 concerns their respective average market-share. Low-leverage firms have, on average, a market-share that is almost double that of High-leverage firms, and the difference is four-fold using median values. Further, to the extent that some of the above differences are a necessary distinguishing factor related to financing choices, we would expect a substantial shift in the values of these ratios in cases where the leverage level changes dramatically. By this we mean a structural break in the capital structure that lasts a few years to limit the noise due to casual vagaries in the leverage ratios. The main problem in performing this exercise is the availability of firms that shift their leverage position, given the high persistence in financing choices. We identify all the firms that undergo a sharp and long-lasting variation in their external book leverage, limiting our analysis to firms with at least seven years of leverage data with at least three consecutive low-leverage years and three high-leverage years. Only 43 firms met these conditions, 18 reduced their external leverage below the low-leverage cutoff point, while 25 shifted high-leverage position. 
Table 1. (a) Descriptive statistics; (b) Industry affiliation and leverage.

(a)

\begin{tabular}{|c|c|c|c|c|c|c|}
\hline & \multicolumn{2}{|c|}{ All Firms } & \multicolumn{2}{|c|}{ Low Leverage Firms } & \multicolumn{2}{|c|}{ High Leverage Firms } \\
\hline & Mean (stdev) & Median & Mean (stdev) & Median & Mean (stdev) & Median \\
\hline Book Leverage $_{\mathrm{TOT}}$ & $40.08(35.48)$ & 43.21 & $6.36(10.92)$ & 1.67 & $73.01(13.23)$ & 75.67 \\
\hline Book Leverage $_{\mathrm{EXT}}$ & $37.98(36.15)$ & 31.24 & $2.95(4.63)$ & 0.51 & $72.18(13.84)$ & 75.42 \\
\hline Persistence & $94.48(11.45)$ & 100 & $95.31(8.89)$ & 100 & $93.67(13.45)$ & 100 \\
\hline Log (Sales) & $11.57(0.82)$ & 11.39 & $11.74(0.90)$ & 11.51 & $11.40(0.71)$ & 11.27 \\
\hline Profitability & $5.80(7.98)$ & 4.04 & $8.77(9.84)$ & 7.28 & $2.89(3.78)$ & 3.01 \\
\hline Depreciation & $3.60(3.42)$ & 2.68 & $4.47(4.07)$ & 3.50 & $2.76(2.36)$ & 2.17 \\
\hline Tangibility & $13.76(14.68)$ & 9.05 & $14.21(15.11)$ & 9.72 & $13.32(14.25)$ & 8.15 \\
\hline Intangibility & $4.96(9.87)$ & 1.29 & $5.21(10.02)$ & 1.29 & $4.71(9.73)$ & 1.29 \\
\hline Total Assets & $156.64(400.07)$ & 64.95 & $187.76(462.14)$ & 81.27 & $125.86(326.03)$ & 53.93 \\
\hline Trade Debt $t_{\mathrm{EXT}}$ & $29.15(18.47)$ & 25.98 & $27.26(19.97)$ & 22.39 & $31.03(16.66)$ & 28.85 \\
\hline Trade Credit ${ }_{\text {EXT }}$ & $42.92(22.81)$ & 41.74 & $38.30(21.87)$ & 35.68 & $47.53(22.82)$ & 46.75 \\
\hline Trade Debt $_{\mathrm{INT}}$ & $8.57(14.66)$ & 2.13 & $13.44(17.38)$ & 6.94 & $3.71(9.00)$ & 0.91 \\
\hline Trade Credit ${ }_{\mathrm{INT}}$ & $8.21(12.98)$ & 2.93 & $12.06(15.69)$ & 5.92 & $4.37(7.88)$ & 1.25 \\
\hline Gross Work Capital & $74.66(20.06)$ & 79.34 & $74.01(20.26)$ & 77.37 & $75.30(19.86)$ & 81.87 \\
\hline Inventory & $18.29(16.50)$ & 14.64 & $15.10(14.24)$ & 11.69 & $21.41(17.91)$ & 18.39 \\
\hline Liquidity & $6.45(8.38)$ & 3.27 & $9.12(10.38)$ & 5.48 & $3.85(4.47)$ & 2.43 \\
\hline Management Owner & $32.70(41.06)$ & 0 & $23.39(40.13)$ & 0 & $41.85(39.93)$ & 36.76 \\
\hline Family Ownership & $57.62(45.65)$ & 83.72 & $45.46(48.22)$ & 0 & $69.58(39.53)$ & 93.76 \\
\hline Treasury Stock & $0.32(1.74)$ & 0 & $0.39(1.93)$ & 0 & $0.25(1.53)$ & 0 \\
\hline Board Size & $4.29(2.38)$ & 4 & $4.49(2.47)$ & 4 & $4.09(2.27)$ & 4 \\
\hline Non-Exec Board \# & $2.54(2.23)$ & 2 & $2.42(2.17)$ & 2 & $2.65(2.28)$ & 2 \\
\hline Mgmt Age & $55.44(10.52)$ & 54 & $55.17(9.98)$ & 53 & $55.50(11.04)$ & 55 \\
\hline Asset Turnover & $1.67(0.98)$ & 1.43 & $1.61(0.96)$ & 1.36 & $1.72(1.00)$ & 1.53 \\
\hline Market Share & $1.95(2.77)$ & 0.89 & $2.55(3.10)$ & 2.06 & $1.36(2.26)$ & 0.55 \\
\hline Obs & 7567 & & 3864 & & 3703 & \\
\hline Firms & 831 & & 409 & & 422 & \\
\hline
\end{tabular}

(b)

\begin{tabular}{|c|c|c|c|c|c|c|}
\hline \multirow[b]{2}{*}{ Sector } & \multicolumn{2}{|r|}{ All Firms } & \multicolumn{2}{|c|}{ Low Leverage } & \multicolumn{2}{|c|}{ High Leverage } \\
\hline & \# Firms & Book Leverage $_{\text {тот }}$ & \# Firms & Book Leverage & \# Firms & Book Leverage $_{\text {тот }}$ \\
\hline Apparel \& Textile & 33 & 34.30 & 21 & 14.71 & 12 & 68.59 \\
\hline Wood \& Paper & 11 & 46.72 & 6 & 21.77 & 5 & 76.67 \\
\hline Food \& Beverage & 54 & 59.32 & 15 & 12.13 & 39 & 77.47 \\
\hline Heavy Manufacturing & 184 & 54.91 & 77 & 27.04 & 107 & 74.97 \\
\hline Chemicals, Rubber \& Oil & 85 & 37.07 & 64 & 26.32 & 21 & 69.85 \\
\hline Commerce & 249 & 55.93 & 115 & 33.04 & 134 & 75.58 \\
\hline Construction & 38 & 56.91 & 13 & 20.73 & 25 & 75.73 \\
\hline Communication & 25 & 31.52 & 19 & 19.54 & 6 & 69.47 \\
\hline $\begin{array}{l}\text { Electronic \& Electric } \\
\text { Equipment }\end{array}$ & 45 & 40.65 & 27 & 20.93 & 18 & 70.24 \\
\hline $\begin{array}{c}\text { Lodging, } \\
\text { Eating \& Amusement }\end{array}$ & 11 & 42.24 & 9 & 34.99 & 2 & 74.88 \\
\hline Transportation & 43 & 45.26 & 21 & 16.81 & 22 & 72.42 \\
\hline Utilities \& Business Services & 53 & 59.00 & 22 & 33.28 & 31 & 77.25 \\
\hline
\end{tabular}


One potential concern with the results here is the limited number of firms that thoroughly modified their capital structure. With this caveat in mind, we start by defining $t$ as the time at which a firm switched from Low to High-leverage or vice-versa. Then we analyze the firm's behavior in terms of leverage, equity, tangible and intangible assets, intra-group and extra-group trade positions, inventory, liquidity, and profitability from $\mathrm{t}-3$ to $\mathrm{t}+$ 3. Figure 1 presents graphs describing firm choices in event time. Panels A and B indicate that Low-leverage

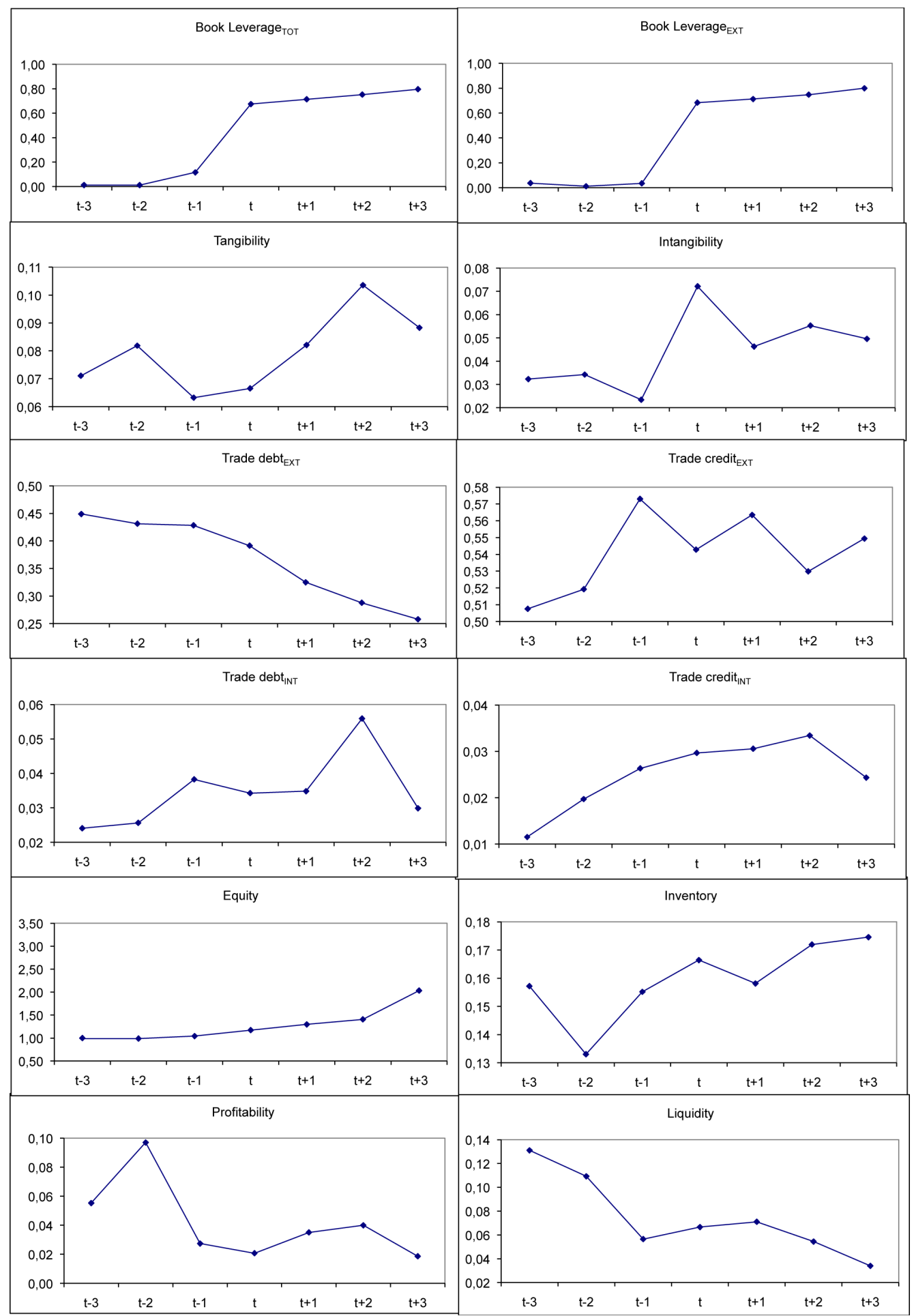

(a) 


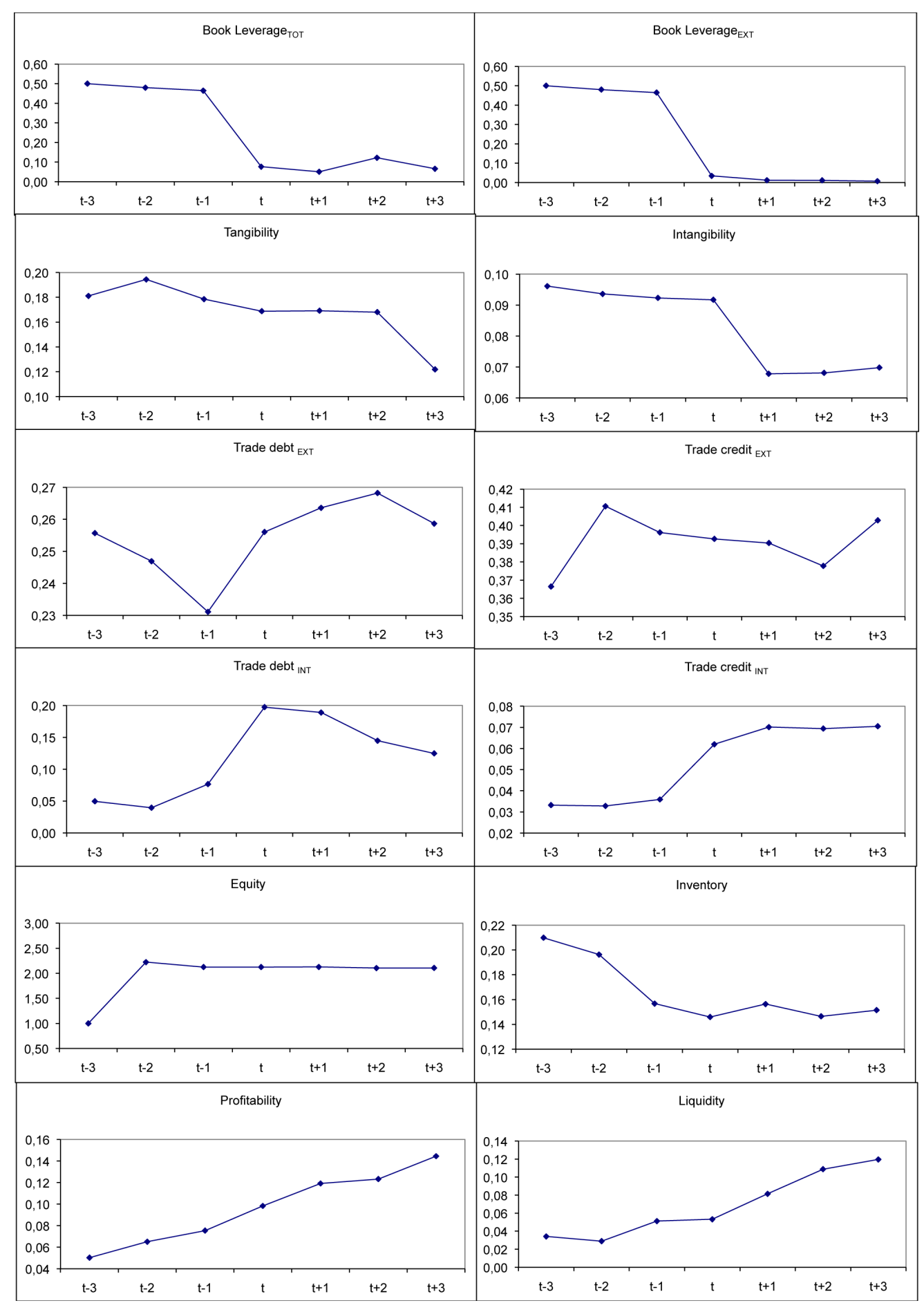

(b)

Figure 1. (a) Low to high subsample indicators; (b) High to low subsample indicators.

firms which shifted to High-leverage status and High-leverage firms that became Low-leverage experience significant changes in all these ratios. In Panel A we document that Low-leverage firms that shift to High-leverage experience a sharp increase in both total and external leverage ratios in just one year from t-1 to $t$. Using as benchmark the equity value of $t-3$, we see that, on average, these firms issue new equity in the years from $t-1$ onward but the effect of this policy on the leverage ratios is limited; it probably helps only to limit creditor wor- 
ries on the sustainability of the new capital structure. Tangible and intangible assets increase with the shift, but with some lag in the case of plant and equipment, while inventory increases rather steadily from $\mathrm{t}-2$ onward. Trade payables decline sharply; however, this trend is the result of two contrasting forces, as we can see comparing intra-group and extra-group payables. On the contrary, intra and extra-group trade receivables both follow an upward trend. The picture depicts a severe decline in liquidity, and a similar trend can be seen in profitability consistently with H1a. Panel B shows the reversed patterns in the case of High-leverage firms shifting to Low-leverage status, consistently with H1b. Overall, Figure 1 results confirm the hypotheses (H1, H1a, H1b) that there is a fundamental relationship between capital structure choices, profitability, liquidity, inventory, and commercial operations in their intra-group and extra-group components. For tangible and intangible assets the evidence is doubtful, as it seems that a change in these ratios follows a shift in leverage. In this case the usual interpretation of tangibility in leverage regressions became problematic. A possible explanation for this puzzle is that tangibility is just a proxy for investments as it represents the stock of investment in net fixed assets at a given moment. An exact analysis of the lead/lag relationship between the same variables is beyond the scope of this paper but it is of the utmost importance in understanding the dynamics of capital structure choices.

\section{Permanent Leverage in Panel Data}

One implication of the results in Table 1 and Figure 1 is that leverage appears to be persistent over time, confirming H1. Significant changes in capital structure seem only to occur if a firm suffers a radical transformation in its characteristics that has long-lasting effects on profitability, liquidity, investments in tangible and intangible assets, trade account payables and receivables. Otherwise, the capital structure is typically stable or fluctuates almost randomly in the short run, with a slowly decaying transitory component in the long run (Lemmon, Roberts and Zender [1]). What is troubling with these results is that traditional determinants explain only a small fraction of the variability in leverage. Further, the relative importance of existing determinants does not adequately explain the cross-sectional as opposed to the time series variability in leverage. We explore these issues performing a panel data analysis. In Table 2 we present the parameter estimates obtained from panel GLS regressions using the full ten-year sample. The t-statistics are computed using standard errors clustered by firm. We use both measures of book leverage, total and external, and run four model specifications separately for low and high-leverage firms and for the joint sample. Panel A shows the results for Low-leverage firms; Panel B shows the results for High-leverage firms. Panel $\mathrm{C}$ shows the results for the full sample. Traditional determinants of leverage used in the first column explain only $23 \%$ of the variability for the full sample; a result in line with previous works based on listed firms. Unsurprisingly, only sales, profitability and cash flow are statistically significant. From a pecking order perspective this inverse relation is reasonable (Gottardo and Moisello [26]). Within the subsamples, the traditional determinants help explain a small fraction of the variability in total leverage. The second and sixth columns show the results of a specification based on managerial and ownership dimensions. In this case, the independent variables are management ownership, management age and treasury stock as well as four dummies to control for the impact of foreign ownership on leverage, the existence of a single shareholder, the status of a holding within a group or that of standalone. Management ownership is never significant while treasury stock, management age, and the dummies for foreign ownership; consistently with $\mathrm{H} 2 \mathrm{a}$ ) and a single shareholder all have a negative and significant impact on leverage. Standalone and holdings are, on average, more levered confirming H2. This second specification accounts for 30\% and 34\% of the variability in total and external leverage, respectively. The third column incorporates into the analysis the trade account positions in their intra-group and extra-group components, the inventory and liquidity ratios, the asset turnover and the average market-share. Higher levels of intra-group trade payables and receivables, and greater liquidity and average market-share are associated with lower levels of leverage, consistently with H1a and H3, while higher inventory levels lead to higher levels of leverage. These factors alone jointly explain the greatest portion of the variability in leverage in the full sample, $34 \%$ for both total and external leverage. The results for these factors are consistent with a pecking order perspective. The final specification incorporates all the above variables in one model. The results show that the full model accounts for more than 53\% (55\%) of the variability for total (external) leverage in the full sample. Our findings complement and extend those in Lemmon, Roberts and Zender [1] as they suggest that, even in the case of private firms, traditional determinants alone explain only $23 \%$ of the variation in cross-sectional leverage. A variance decomposition exercise in Lemmon, Roberts and Zender [1] indicates that firm fixed effects account for as much as $60 \%$ of the variability and our final model 
Table 2. Determinants of book leverage. Panel data analysis. (a) Low leverage firms; (b) High leverage firms; (c) All firms.

(a)

\begin{tabular}{|c|c|c|c|c|c|c|c|c|}
\hline \multirow[t]{2}{*}{ Variable } & \multicolumn{4}{|c|}{ Book Leverage } & \multicolumn{4}{|c|}{ Book Leverage $_{\mathrm{EXT}}$} \\
\hline & (1) & (2) & (3) & (4) & (5) & (6) & (7) & $(8)$ \\
\hline Log (Sales) & $0.00(0.61)$ & & & $0.00(0.57)$ & $-0.00(-0.59)$ & & & $0.01(1.57)$ \\
\hline Tangibility & $0.05(1.82)$ & & & $0.00(0.09)$ & $0.01(2.55)$ & & & $0.00(-0.12)$ \\
\hline Intangibility & $0.23(3.25)$ & & & $0.20(2.47)$ & $0.00(0.20)$ & & & $0.00(0.86)$ \\
\hline Profitability & $-0.09(-2.51)$ & & & & $-0.01(-2.22)$ & & & $-0.00(-0.47)$ \\
\hline Cash Flow & $-0.12(-2.34)$ & & & $-0.20(-3.42)$ & $0.00(0.49)$ & & & \\
\hline Mngmt Owner & & $0.00(0.26)$ & & $0.00(0.48)$ & & $0.00(1.97)$ & & $-0.01(-1.87)$ \\
\hline Treasury Stock & & $-0.00(-0.89)$ & & $-0.00(-1.37)$ & & $0.00(1.28)$ & & $0.00(1.43)$ \\
\hline D FOREIGN-OWN & & $0.02(1.01)$ & & $0.02(0.92)$ & & $-0.00(-0.70)$ & & $0.00(0.92)$ \\
\hline Mgmt Age & & $-0.00(-2.41)$ & & $-0.00(-1.37)$ & & $-0.00(-0.39)$ & & $-0.00(-1.81)$ \\
\hline D $_{\text {StAND ALONE }}$ & & $-0.01(-0.54)$ & & $-0.01(-0.79)$ & & $0.01(1.11)$ & & $-0.00(-1.17)$ \\
\hline $\mathrm{D}_{\text {HOLDING }}$ & & $0.02(1.34)$ & & $0.01(0.71)$ & & $-0.00(-0.37)$ & & $0.01(1.42)$ \\
\hline D $_{\text {SHAREHOLDER }}$ & & $0.02(2.21)$ & & $0.02(1.60)$ & & $0.00(0.87)$ & & $-0.00(0.24)$ \\
\hline Trade Debt ${ }_{\text {EXT }}$ & & & $-0.04(-1.78)$ & $-0.06(-2.54)$ & & & $-0.00(-0.26)$ & $0.00(1.22)$ \\
\hline Trade Credit ${ }_{\text {EXT }}$ & & & $-0.05(-2.56)$ & $-0.03(-0.99)$ & & & $-0.00(-1.02)$ & $-0.00(-0.46)$ \\
\hline Trade Debt $_{\mathrm{INT}}$ & & & $-0.08(-3.27)$ & $-0.12(-4.09)$ & & & $-0.01(-3.32)$ & $0.00(0.65)$ \\
\hline Trade Credit & & & $-0.07(-3.07)$ & $-0.07(-2.07)$ & & & $-0.01(-1.94)$ & $-0.01(-2.69)$ \\
\hline Inventory & & & $-0.03(-0.79)$ & $-0.00(-0.05)$ & & & $-0.00(-0.37)$ & $-0.01(-2.33)$ \\
\hline Liquidity & & & $-0.19(-5.64)$ & $-0.11(-2.66)$ & & & $-0.01(-2.35)$ & $-0.00(-0.72)$ \\
\hline Asset Turnover & & & $-0.00(-0.41)$ & $0.00(0.16)$ & & & $-0.00(-1.93)$ & $-0.02(-3.14)$ \\
\hline Market Share & & & $-0.39(-2.07)$ & $-0.16(-0.92)$ & & & $0.00(0.05)$ & $-0.00(-2.02)$ \\
\hline $\begin{array}{l}\text { Industry } \\
\text { Dummies }\end{array}$ & yes & yes & yes & yes & yes & yes & yes & yes \\
\hline $\mathrm{N}$ & 4122 & 4146 & 3484 & 3384 & 4122 & 4146 & 3484 & 3384 \\
\hline $\mathrm{R}^{2}$ & 0.07 & 0.04 & 0.06 & 0.11 & 0.07 & 0.08 & 0.07 & 0.10 \\
\hline
\end{tabular}

(b)

\begin{tabular}{|c|c|c|c|c|c|c|c|c|}
\hline \multirow[t]{2}{*}{ Variable } & \multicolumn{4}{|c|}{ Book Leverage $_{\mathrm{TOT}}$} & \multicolumn{4}{|c|}{ Book Leverage $_{\mathrm{EXT}}$} \\
\hline & (1) & (2) & (3) & (4) & (5) & (6) & (7) & (8) \\
\hline Log (Sales) & $0.01(1.21)$ & & & $0.01(1.15)$ & $0.01(1.16)$ & & & $0.01(1.30)$ \\
\hline Tangibility & $-0.05(-1.47)$ & & & $0.21(4.29)$ & $-0.05(-1.45)$ & & & $0.21(4.33)$ \\
\hline Intangibility & $-0.06(-0.91)$ & & & $0.25(3.16)$ & $-0.08(-1.28)$ & & & $0.22(2.78)$ \\
\hline Profitability & $-0.02(-0.19)$ & & & & $-0.02(-0.18)$ & & & \\
\hline Cash Flow & $-0.69(-4.67)$ & & & $-0.70(-7.48)$ & $-0.68(-4.56)$ & & & $-0.68(-7.19)$ \\
\hline Mngmt Owner & & $-0.00(-0.63)$ & & $0.00(0.03)$ & & $-0.00(-0.65)$ & & $-0.00(-0.13)$ \\
\hline Treasury Stock & & $-0.00(-1.78)$ & & $-0.01(-1.91)$ & & $-0.00(-1.70)$ & & $-0.00(-1.82)$ \\
\hline D FOREIGN-OWN $_{\text {Fin }}$ & & $-0.03(-1.64)$ & & $-0.05(-2.68)$ & & $-0.04(-2.08)$ & & $-0.05(-3.05)$ \\
\hline Mgmt Age & & $0.00(0.54)$ & & $0.00(0.06)$ & & $0.00(0.45)$ & & $0.00(0.05)$ \\
\hline D $_{\text {STAND ALONE }}$ & & $0.01(1.31)$ & & $0.01(1.05)$ & & $0.01(1.29)$ & & $0.01(1.04)$ \\
\hline $\mathrm{D}_{\text {HOLDING }}$ & & $-0.00(-0.16)$ & & $-0.00(-0.03)$ & & $-0.00(-0.00)$ & & $0.00(0.09)$ \\
\hline $\mathrm{D}_{\text {SHAREHOLDER }}$ & & $0.00(0.09)$ & & $0.00(0.14)$ & & $-0.00(-0.14)$ & & $-0.00(-0.01)$ \\
\hline Trade Debt ${ }_{\mathrm{EXT}}$ & & & $-0.06(-2.35)$ & $-0.08(-3.19)$ & & & $-0.06(-2.24)$ & $-0.08(-3.06)$ \\
\hline Trade Credit EXT & & & $0.13(4.64)$ & $0.28(5.75)$ & & & $0.14(4.74)$ & $0.28(5.86)$ \\
\hline Trade Debt ${ }_{\mathrm{INT}}$ & & & $-0.11(-2.13)$ & $-0.13(-2.58)$ & & & $-0.12(-2.27)$ & $-0.13(-2.59)$ \\
\hline Trade Credit ${ }_{\text {INT }}$ & & & $0.06(1.29)$ & $0.22(3.51)$ & & & $0.07(1.28)$ & $0.21(3.24)$ \\
\hline Inventory & & & $0.12(3.96)$ & $0.26(5.42)$ & & & $0.13(4.07)$ & $0.26(5.45)$ \\
\hline Liquidity & & & $-0.17(-2.12)$ & $0.04(0.44)$ & & & $-0.15(-1.95)$ & $0.04(0.48)$ \\
\hline Asset Turnover & & & $-0.00(-0.11)$ & $0.00(0.04)$ & & & $-0.00(-0.20)$ & $-0.00(-0.15)$ \\
\hline Market Share & & & $0.42(1.19)$ & $0.59(2.19)$ & & & $0.39(1.16)$ & $0.58(2.27)$ \\
\hline $\begin{array}{l}\text { Industry } \\
\text { Dummies }\end{array}$ & yes & yes & yes & yes & yes & yes & yes & yes \\
\hline $\mathrm{N}$ & 3948 & 3905 & 3204 & 3159 & 3948 & 3905 & 3204 & 3159 \\
\hline $\mathrm{R}^{2}$ & 0.14 & 0.08 & 0.13 & 0.22 & 0.14 & 0.09 & 0.13 & 0.21 \\
\hline
\end{tabular}


(c)

\begin{tabular}{|c|c|c|c|c|c|c|c|c|}
\hline \multirow[t]{2}{*}{ Variable } & \multicolumn{4}{|c|}{ Book Leverage $_{\text {Tот }}$} & \multicolumn{4}{|c|}{ Book Leverage $\mathrm{EXX}_{\mathrm{EX}}$} \\
\hline & (1) & (2) & (3) & (4) & (5) & (6) & (7) & (8) \\
\hline Log (Sales) & $-0.03(-2.95)$ & & & $-0.00(-0.45)$ & $-0.03(-3.24)$ & & & $-0.01(-0.63)$ \\
\hline Tangibility & $0.03(0.35)$ & & & $-0.05(-0.59)$ & $0.01(0.11)$ & & & $-0.05(-0.64)$ \\
\hline Intangibility & $0.13(1.29)$ & & & $0.30(2.83)$ & $-0.00(-0.01)$ & & & $0.19(1.75)$ \\
\hline Profitability & $-0.46(-2.62)$ & & & & $-0.41(-2.42)$ & & & \\
\hline Cash Flow & $-1.03(-4.06)$ & & & $-1.03(-5.61)$ & $-0.99(-4.02)$ & & & $-0.93(-5.46)$ \\
\hline Mngmt Owner & & $-0.00(-0.62)$ & & $-0.00(-0.27)$ & & $-0.00(-0.50)$ & & $-0.00(-0.29)$ \\
\hline Treasury Stock & & $-0.02(-3.16)$ & & $-0.02(-4.16)$ & & $-0.02(-3.05)$ & & $-0.02(-3.93)$ \\
\hline D FOREIGN-OWN & & $\begin{array}{c}-0.32 \\
(-10.48)\end{array}$ & & $-0.25(-9.41)$ & & $\begin{array}{c}-0.34 \\
(-11.40)\end{array}$ & & $\begin{array}{c}-0.29 \\
(-10.52)\end{array}$ \\
\hline Mgmt Age & & $-0.00(-3.67)$ & & $-0.00(-2.77)$ & & $-0.00(-3.35)$ & & $-0.00(-2.60)$ \\
\hline D $_{\text {Stand ALone }}$ & & $0.11(3.03)$ & & $0.07(2.42)$ & & $0.11(3.15)$ & & $0.08(2.61)$ \\
\hline $\mathrm{D}_{\text {HOLDING }}$ & & $0.12(3.80)$ & & $0.08(3.11)$ & & $0.12(3.76)$ & & $0.08(3.12)$ \\
\hline $\mathrm{D}_{\text {SHAREHOLDER }}$ & & $-0.07(-3.10)$ & & $-0.05(-2.47)$ & & $-0.09(-3.73)$ & & $-0.06(-3.04)$ \\
\hline Trade Debt ${ }_{\mathrm{EXT}}$ & & & $-0.13(-2.08)$ & $-0.23(-4.82)$ & & & $-0.11(-1.81)$ & $-0.21(-4.39)$ \\
\hline Trade Credit $_{\mathrm{EXT}}$ & & & $0.02(0.37)$ & $0.12(2.07)$ & & & $0.05(0.97)$ & $0.14(2.48)$ \\
\hline Trade Debt ${ }_{\text {INT }}$ & & & $\begin{array}{c}-0.71 \\
(-10.83)\end{array}$ & $-0.53(-8.90)$ & & & $\begin{array}{c}-0.71 \\
(-10.86)\end{array}$ & $-0.49(-8.57)$ \\
\hline Trade Credit $_{\text {INT }}$ & & & $-0.17(-1.73)$ & $-0.26(-3.30)$ & & & $-0.14(-1.38)$ & $-0.24(3.15)$ \\
\hline Inventory & & & $0.29(4.02)$ & $0.17(2.50)$ & & & $0.33(4.47)$ & $0.18(2.63)$ \\
\hline Liquidity & & & $\begin{array}{c}-1.23 \\
(-14.67)\end{array}$ & $\begin{array}{c}-1.05 \\
(-10.33)\end{array}$ & & & $\begin{array}{c}-1.15 \\
(-13.63)\end{array}$ & $\begin{array}{c}-1.02 \\
(-10.19)\end{array}$ \\
\hline Asset Turnover & & & $0.01(1.17)$ & $0.01(1.12)$ & & & $0.01(1.28)$ & $0.01(0.96)$ \\
\hline Market Share & & & $-2.56(-4.19)$ & $-1.16(-2.02)$ & & & $-2.65(-4.26)$ & $-1.14(-1.95)$ \\
\hline $\begin{array}{l}\text { Industry } \\
\text { Dummies }\end{array}$ & yes & yes & yes & yes & yes & yes & yes & yes \\
\hline $\mathrm{N}$ & 8070 & 8051 & 6688 & 6545 & 8070 & 8051 & 6688 & 6545 \\
\hline $\mathrm{R}^{2}$ & 0.23 & 0.30 & 0.34 & 0.53 & 0.22 & 0.34 & 0.34 & 0.55 \\
\hline
\end{tabular}

specifications explicitly explains $53 \%$ or $55 \%$ of the variation in leverage. Most of the explanatory power is linked to the additional variables introduced in our second and third specification: the dummies to control for foreign ownership, single ownership, holding or standalone, the treasury stock ratio, trade debt and credit ratios, liquidity, inventory, and average market-share. The intra and extra-group commercial trade components, together with profitability, liquidity, and average market-share, are among the most influential factors in these regressions. The -0.53 estimated coefficient in column 4 implies that a $10 \%$ higher Trade Debt ${ }_{\text {INT }}$ is associated with a firm total leverage ratio that is $-5.3 \%$ lower. Our results corroborate the observation in Lemmon, Roberts and Zender [1] that extant capital structure determinants essentially explain the cross-sectional heterogeneity in leverage while they have little to say about the time series variability. The panel results reveal an interesting finding: the full sample final specification estimates in column (4) and (8) indicate that industry dummies are never significant at the $1 \%$ level, suggesting that introducing the variables of our second and third specification captures a sizeable share of the inter-industry variability in leverage.

\section{Discussion}

Two of the main challenges facing the capital structure literature are posed by the endogeneity problem and the lack of a structural model. The usual solution to mitigate concern about endogenous variables is to use one-year 
lagged determinants instead of contemporaneous observations. Unfortunately this is not a satisfactory solution for this problem, given the high degree of persistence in the leverage measures. Differencing the time series is not a solution either as the procedure eliminates most of the variability in leverage and the persistency itself; however, it may be useful in studies of the financial structure dynamics. Another solution would be a simultaneous equation estimate as, after all, capital structure choices are linked to many other managerial and financial decisions, such as capital investments, trade credit and debt, liquidity and inventory choices. However, all of them are linked to profitability, cash-flows, and, ultimately, to a firm's market power. A structural model linking these and other relevant factors would be a useful starting point to make new inferences and test the robustness of previous findings, however we still lack such a model. Table 3 shows some preliminary results obtained by running a simultaneous equation model where we estimate jointly the coefficients using a full information maximum likelihood procedure (FIML). Building on the above results, we estimate a six-equation model linking the external book leverage, the intra-group leverage, the tangibility and intangibility ratios, the liquidity and the profitability ratios. In the equations we control for industry membership using dummies and, to save degrees of freedom, we estimate a somewhat reduced model for leverage that captures the most relevant determinants found in Table 2. Rather than examine each equation result separately, we outline broad patterns across equations, drawing attention to the statistically significant coefficients. Cash-flows are strongly linked with all left-hand side variables; the coefficient is negative with external leverage, and intra-group leverage positive with tangible assets, intangible assets, and liquidity. Size is negatively related with liquidity and positively with intangible assets. The negative relation with leverage was already found in the panel data analyses and is in line with the results for German firms in Rajan and Zingales [27] and the predictions of the pecking order theory (Gottardo and Moisello [26]). The dummy to control for foreign ownership has a negative coefficient in the external leverage equation while it is positive with intra-group leverage and profitability signaling substantial differences between domestic firms and Italian affiliates of foreign firms that go beyond the debt/equity choice. The standalone dummy captures the impact of differential characteristics of this kind of firm with respect to the average firm that operates within a group. The results show a positive link with external leverage and tangibility and a negative one with intangible assets and profitability. The holding dummy has a positive coefficient in external leverage and tangibility equations and a negative one in intangible assets and profitability equations. The dummy to control for the existence of a unique shareholder is negatively related with external leverage, liquidity and profitability and positively related with intra-group leverage. The asset turnover ratio has a positive coefficient in the liquidity and profitability equations while the correlation is negative with intra-group leverage, tangible and intangible assets. Average market-share is negatively related with external leverage and intangible

Table 3. Simultaneous equations. Full-information maximum likelihood results.

\begin{tabular}{|c|c|c|c|c|c|c|}
\hline & Book Lev EXT & $\begin{array}{l}\text { Intra-Group } \\
\text { Leverage }\end{array}$ & Tang & Intang & Liquidity & Profitability \\
\hline Cash Flow & $-0.81(-20.31)$ & $-0.03(-2.43)$ & $0.36(18.98)$ & $0.09(7.35)$ & $0.05(4.49)$ & \\
\hline Log (Sales) & $-0.01(-1.25)$ & $0.00(1.88)$ & $-0.00(-0.32)$ & $0.01(7.26)$ & $-0.00(-2.12)$ & $0.00(1.93)$ \\
\hline D FOREIGN-OWN & $-0.32(-33.48)$ & $0.03(9.39)$ & $-0.00(-0.35)$ & $-0.00(-0.52)$ & $-0.00(-0.54)$ & $0.02(6.94)$ \\
\hline $\mathrm{D}_{\mathrm{STAND}}$ ALONE & $0.09(7.22)$ & $-0.00(-1.09)$ & $0.03(4.71)$ & $-0.02(-4.16)$ & $0.01(1.34)$ & $-0.01(-3.41)$ \\
\hline $\mathrm{D}_{\text {HOLDING }}$ & $0.08(6.65)$ & $-0.00(-0.41)$ & $0.03(5.14)$ & $-0.01(-3.72)$ & $0.00(1.06)$ & $-0.01(-2.33)$ \\
\hline $\mathrm{D}_{\text {SHAREHOLDER }}$ & $-0.08(-9.90)$ & $0.01(3.59)$ & $0.00(0.90)$ & $0.00(0.32)$ & $-0.01(-2.98)$ & $-0.01(-4.45)$ \\
\hline Asset Turnover & $-0.00(-0.55)$ & $-0.00(-2.98)$ & $-0.03(-16.99)$ & $-0.02(-16.30)$ & $0.01(3.90)$ & $0.02(13.84)$ \\
\hline Market Share & $-1.74(-8.96)$ & $-0.05(-0.75)$ & $0.61(6.43)$ & $-0.16(-2.71)$ & $0.31(5.12)$ & $0.32(5.22)$ \\
\hline Management Age & $-0.00(-9.87)$ & $-0.00(-1.60)$ & $0.00(0.22)$ & $-0.00(-6.83)$ & $0.00(10.96)$ & $0.00(9.35)$ \\
\hline Commercial Balance $_{\mathrm{INT}}$ & $0.09(4.53)$ & $0.01(1.54)$ & $-0.07(-7.21)$ & $-0.05(-7.94)$ & & \\
\hline Commercial Balance $_{\mathrm{EXT}}$ & $0.13(9.71)$ & $-0.00(-0.98)$ & $-0.09(-14.06)$ & $-0.06(-14.35)$ & & \\
\hline Industry Dummies & yes & yes & yes & yes & yes & yes \\
\hline Observations & 6545 & & & & & \\
\hline
\end{tabular}


assets while the relation is positive with tangible assets, liquidity and profitability. Management age has a negative impact on external leverage and intangible assets, while the relation is positive with liquidity, and profitability. Both measures of trade-balance, Commercial Balance $\mathrm{INT}_{\mathrm{NT}}$ (Commercial Balance $\mathrm{EXT}_{\mathrm{ET}}$ ), defined as the difference between intra-group (extra-group) receivables and payables, are positively related with external leverage, and the correlation is negative with tangible and intangible assets. The simultaneous equation results for external leverage are substantially the same as those found in the panel analysis, and this can help mitigate concerns about endogeneity problems.

\section{Conclusions, Limitations and Further Research}

This paper studies privately-held Italian firms to determine which factors explain two of the most puzzling peculiarities of the capital structure of firms: the persistence in leverage ratios and their extreme cross-sectional variability. Our findings seem to show that many firms have a strong cash-flow generation capability. They use this capability to preserve their leading position or to improve it with a whole set of strategies that comprises cash stockpiling, low to moderate external leverage levels, the efficient use of internal capital markets, a competitive position in the commercial trade credit and debt markets and a strict control on inventory levels. This evidence is consistent with a pecking order perspective, but we need an "augmented" model to account for the evidence that ownership, business group membership and management factors have an important effect on capital structure. A number of open questions remain. Tangibility and intangibility have a limited explanatory power for Italian firms, but the sign and significance of their coefficients change in the full models in columns 4 and 8 in Table 2. Our interpretation is that this puzzling evidence appears to be due to the negative correlation that exists between these two ratios and the commercial trade ratios, in particular the extra-group ratios and the inventory ratio. It can be argued that this is related to a firm's choice between investing in fixed and intangible assets or in liquid assets, but we don't know if this is the result of external constraints linked to the availability of funds or a voluntary choice. However, given that these effects are stronger for the High-leveraged firms, the answer is probably connected to their particular situation. The equation system explanatory power certainly depends on the specification of each equation. The liquidity and profitability equations above are simply defined and there is plenty of room for improvement but our understanding of the internal markets, either capital markets or trade credit markets, is also elementary and needs more careful scrutiny. Last but not least, in all simultaneous equation estimation methods, individual parameter estimates are sensitive, by construction, to the full model specification. There is an unavoidable trade-off between greater efficiency and potential specification error. With these caveats in mind, the evidence supports the view that capital structure decisions and product market outcomes are strictly intertwined: Low-leverage firms have higher average market-share, and, at the same time, they are more profitable and hold larger cash balances, an outcome broadly consistent with the pecking order predictions and our hypotheses ( $\mathrm{H} 1 \mathrm{~b}, \mathrm{H} 3)$. It would be interesting to include an equation for market-share in the system but the information set is too limited for this, as a firm's market-share is the result of imponderable and hard-to-quantify factors related to technologies, output quality, managerial characteristics and competing firms' behavior. We have not studied here the dynamics of capital structure, focalizing on the permanent component. A characterization of dynamic effects necessarily implies a system based on flows rather than stocks and the choice of the optimal time interval, as one-year datum is probably too noisy to accurately measure any dynamic effect. Having said this, longer intervals imply shorter time series and could result in other shortcomings. This explorative study points out the role of the internal capital markets and market share in the persistence of Low and High levered capital structures and the empirical findings should support corporate managers in making correct financing decisions. Our findings probably raise more questions than answers; certainly they point to the existence of ties between capital structure, market power, cash-flows, ownership and balance sheet structure being more complex than previously portrayed. They all suggest that more research should be undertaken in the field.

\section{References}

[1] Lemmon, M.L., Roberts, M.R. and Zender, J.F. (2008) Back to the Beginning: Persistence and the Cross-Section of Corporate Capital Structure. Journal of Finance, 63, 1575-1608. http://dx.doi.org/10.1111/j.1540-6261.2008.01369.x

[2] Strebulaev, I.A. and Yang, B. (2013) The Mystery of Zero-Leverage Firm. Journal of Financial Economics, $109,1-23$. http://dx.doi.org/10.1016/j.jfineco.2013.02.001

[3] Keynes, J.M. (1936) The General Theory of Employment, Interest and Money. MacMillan Cambridge University 
Press, Cambridge.

[4] Bolton, P., Chen, H. and Wang, N. (2011) A Unified Theory of Tobin's $q$, Corporate Investment, Financing, and Risk Management. Journal of Finance, 66, 1545-1578. http://dx.doi.org/10.1111/j.1540-6261.2011.01681.x

[5] Lamont, O. (1997) Cash-Flow and Investment: Evidence from Internal Capital Markets. Journal of Finance, 52, 83109. http://dx.doi.org/10.1111/j.1540-6261.1997.tb03809.x

[6] Inderst, R. and Müller, H.M. (2003) Internal versus External Financing: An Optimal Contracting Approach. Journal of Finance, 58, 1033-1062. http://dx.doi.org/10.1111/1540-6261.00557

[7] Jensen, M.C. (1986) Agency Costs of Free Cash-Flow, Corporate Finance, and Takeovers. American Economic Review Papers and Proceedings, 76, 323-329.

[8] Opler, T., Pinkowitz, L., Stulz, R. and Williamson, R. (1999) The Determinants and Implications of Cash Holdings. Journal of Financial Economics, 52, 3-46. http://dx.doi.org/10.1016/S0304-405X(99)00003-3

[9] Gamba, A. and Triantis, A. (2008) The Value of Financial Flexibility. Journal of Finance, 63, 2263-2296. http://dx.doi.org/10.1111/j.1540-6261.2008.01397.x

[10] Chevalier, J. (1995) Capital Structure and Product Market Competition: Empirical Evidence from the Supermarket Industry. American Economic Review, 85, 415-435.

[11] Myers, S.C. and Majluf, N.S. (1984) Corporate Financing and Investment Decisions When Firms Have Information That Investors Do Not Have. Journal of Financial Economics, 13, 187-221. http://dx.doi.org/10.1016/0304-405X(84)90023-0

[12] Franks, J. and Mayer, C. (2001) Ownership and Control of German Corporations. Review of Financial Studies, 14, 943-977. http://dx.doi.org/10.1093/rfs/14.4.943

[13] Cestone, G. and Fumagalli, C. (2005) The Strategic Impact of Resource Flexibility in Business. Rand Journal of Economics, 36, 193-214.

[14] Meyer, J.R. and Kuh, E. (1957) The Investment Decision: An Empirical Study. Harvard University Press, Cambridge, MA. http://dx.doi.org/10.4159/harvard.9780674421189

[15] Mathews, R.D. and Robinson, D.T. (2008) Market Structure, Internal Capital Markets, and the Boundaries of the Firm. Journal of Finance, 63, 2703-2736. http://dx.doi.org/10.1111/j.1540-6261.2008.01395.x

[16] Scharfstein, D.S. and Stein, J.C. (2000) The Dark Side of Internal Capital Markets: Divisional Rent-Seeking and Inefficient Investment. Journal of Finance, 55, 2537-2564. http://dx.doi.org/10.1111/0022-1082.00299

[17] Stein, J.C. (1997) Internal Capital Markets and the Competition for Corporate Resources. Journal of Finance, 52, 111 133. http://dx.doi.org/10.1111/j.1540-6261.1997.tb03810.x

[18] Piga, C.A.G. (2002) Debt and Firms Relationships: The Italian Evidence. Review of Industrial Organization, 20, $267-$ 282. http://dx.doi.org/10.1023/A:1015047625588

[19] Bianco, M. and Nicodano, G. (2006) Pyramidal Groups and Debt. European Economic Review, 50, 937-961. http://dx.doi.org/10.1016/j.euroecorev.2004.11.001

[20] Desai, M.A., Foley, C.F. and Hines Jr., J.R. (2004) A Multinational Perspective on Capital Structure Choice and Internal Capital Markets. Journal of Finance, 59, 2451-2487. http://dx.doi.org/10.1111/j.1540-6261.2004.00706.x

[21] Zingales, L. (1998) Survival of the Fittest or the Fattest? Exit and Financing in the Trucking Industry. Journal of Finance, 53, 905-938. http://dx.doi.org/10.1111/0022-1082.00039

[22] MacKay, P. and Phillips, G.M. (2005) How Does Industry Affect Firm Financial Structure? Review of Financial Studies, 18, 1433-1466. http://dx.doi.org/10.1093/rfs/hhi032

[23] Campello, M. (2006) Debt Financing: Does It Boost or Hurt Firm Performance in Product Markets? Journal of Financial Economics, 82, 135-172. http://dx.doi.org/10.1016/j.jfineco.2005.04.001

[24] Barclay, M.J. and Smith, C.W. (2005) The Capital Structure Puzzle: The Evidence Revisited. Journal of Applied Corporate Finance, 17, 8-17. http://dx.doi.org/10.1111/j.1745-6622.2005.012_2.x

[25] Harris, M. and Raviv, A. (1991) The Theory of Capital Structure. Journal of Finance, 46, 297-355. http://dx.doi.org/10.1111/j.1540-6261.1991.tb03753.x

[26] Gottardo, P. and Moisello, A.M. (2014) The Capital Structure Choices of Family Firms. Evidence from Italian Medium-Large Unlisted Firms. Managerial Finance, 40, 254-275. http://dx.doi.org/10.1108/MF-03-2013-0065

[27] Rajan, R. and Zingales, L. (1995) What Do We Know about Capital Structure? Some Evidence from International Data. Journal of Finance, 50, 1421-1460. http://dx.doi.org/10.1111/j.1540-6261.1995.tb05184.x 